University of Nebraska - Lincoln

DigitalCommons@University of Nebraska - Lincoln

2003

\title{
New Haplotypes of the Plasmodium falciparum Chloroquine Resistance Transporter (PFCRT) Gene Among Chloroquine- Resistant Parasite Isolates
}

\author{
Hadya S. Nagesha \\ The Walter and Eliza Hall Institute of Medical Research, hadya@wehi.edu.au \\ Gerard J. Casey \\ The Walter and Eliza Hall Institute of Medical Research \\ Karl H. Rieckmann \\ Australian Army Malaria Institute \\ David J. Fryauff \\ United States Naval Medical Research Unit \# 2 \\ Budi S. Laksana \\ United States Naval Medical Research Unit \# 2
}

See next page for additional authors

Follow this and additional works at: https://digitalcommons.unl.edu/usnavyresearch

Nagesha, Hadya S.; Casey, Gerard J.; Rieckmann, Karl H.; Fryauff, David J.; Laksana, Budi S.; Reeder, John C.; Maguire, Jason D.; and Baird, J. Kevin, "New Haplotypes of the Plasmodium falciparum Chloroquine Resistance Transporter (PFCRT) Gene Among Chloroquine-Resistant Parasite Isolates" (2003). U.S. Navy Research. 57.

https://digitalcommons.unl.edu/usnavyresearch/57

This Article is brought to you for free and open access by the U.S. Department of Defense at DigitalCommons@University of Nebraska - Lincoln. It has been accepted for inclusion in U.S. Navy Research by an authorized administrator of DigitalCommons@University of Nebraska - Lincoln. 


\section{Authors}

Hadya S. Nagesha, Gerard J. Casey, Karl H. Rieckmann, David J. Fryauff, Budi S. Laksana, John C. Reeder, Jason D. Maguire, and J. Kevin Baird 


\title{
NEW HAPLOTYPES OF THE PLASMODIUM FALCIPARUM CHLOROQUINE RESISTANCE TRANSPORTER (PFCRT) GENE AMONG CHLOROQUINE-RESISTANT PARASITE ISOLATES
}

\author{
HADYA S. NAGESHA, GERARD J. CASEY, KARL H. RIECKMANN, DAVID J. FRYAUFF, BUDI S. LAKSANA, \\ JOHN C. REEDER, JASON D. MAGUIRE, AND J. KEVIN BAIRD \\ The Walter and Eliza Hall Institute for Medical Research, Melbourne, Australia; Eijkman Institute for Molecular Biology, Jakarta, \\ Indonesia; United States Naval Medical Research Unit No. 2, U.S. Embassy, Jakarta, Indonesia; Papua New Guinea Institute of \\ Medical Research, Goroka, Papua New Guinea; Australian Army Malaria Institute, Brisbane, Australia
}

Abstract. Mutations in the Plasmodium falciparum chloroquine resistance transporter ( $p f c r t$ ) gene were examined to assess their associations with chloroquine resistance in clinical samples from Armopa (Papua) and Papua New Guinea. In Papua, two of the five $p f c r t$ haplotypes found were new: SVIET from Armopa and CVIKT from an isolate in Timika. There was also a strong association $(P<0.0001)$ between the $p f c r t 76 \mathrm{~T}$ allele and chloroquine resistance in 50 samples. In Papua New Guinea, mutations in the pfcrt gene were observed in 15 isolates with chloroquine minimum inhibitory concentrations (MICs) of 16-64 pmol, while the remaining six isolates, which had a wild-type pfcrt gene at codon 76, had MICs of 2-8 pmol. These observations confirm that mutations at codon 76 in the pfcrt gene are present in both in vivo and in vitro cases of chloroquine resistance, and that detection of the pfcrt $76 \mathrm{~T}$ allele could predict potential chloroquine treatment failures.

\section{INTRODUCTION}

Chloroquine has been the drug of choice for treating malaria patients for the last 50 years, but the spread of drugresistant Plasmodium falciparum has become a major problem. In Southeast Asia, 21.9 million cases of malaria were reported in 1995 alone. ${ }^{1,2}$ Malaria is a serious problem in the eastern islands of Indonesia and in nearby Papua New Guinea. Approximately $20-30 \%$ of the population in these regions typically carry malaria parasites at any given time. In addition, $20 \%$ of consultations, $16 \%$ of hospital admissions, and $14 \%$ of hospital deaths are attributable to malaria. ${ }^{1,2}$

Papuan Indonesia (formerly Irian Jaya) and Papua New Guinea have long been plagued by drug-resistant malaria. Resistance to pyrimethamine and chloroquine in the ArsoWaris-Upper Tor River areas of Papuan Indonesia is believed to have arisen in 1959-1961 with the mass distribution of medicated chloroquine and pyrimethamine salts. ${ }^{3}$ Resistance of $P$. falciparum to chloroquine was reported from Kalimantan in 1973 and from Papua in 1975.,5 An increased risk of chloroquine resistance was reported from the Jayapura region of Papua, Indonesia in the1980s. ${ }^{6,7}$ Surveys conducted during the 1990 s showed high malaria prevalence rates (60-92\%) and levels of chloroquine treatment failure of up to $80 \%$ among indigenous and immigrant communities of northern and central Papuan Indonesia. ${ }^{8-12}$ However, due to its safety profile, low cost, and relative success in treating mildly symptomatic malaria infections among immune and semi-immune patients, chloroquine remains the treatment of choice for malaria, and no effective alternative strategy has been developed. Molecular markers of drug resistance in $P$. falciparum could prove useful in defining the intensity of resistance in an individual patient and the extent and severity of the problem in communities.

The aim of this study was to examine $P$. falciparum chloroquine resistance transporter ( $p f c r t$ ) gene haplotypes in parasite isolates with known in vivo or in vitro chloroquine resistance responses.

\section{MATERIALS AND METHODS}

The Armopa region is located on the northwestern coast of Indonesian Papua. Prior to Javanese transmigration in 1995, there were small traditional villages and a single health clinic in Armopa. No mass treatment or prophylaxis was practiced before transmigrant arrivals, and the indigenous people of Armopa did not use antimalarial drugs for prophylaxis. However, chloroquine, Fansidar ${ }^{\circledR}$ (pyrimethamine and sulfadoxine) (F. Hoffmann La Roche, Basel, Switzerland), and quinine were presumably available for treatment of clinical malaria. Transmigrants, primarily from malaria-free Java and Bali, had no previous exposure to malaria and no history of antimalarial drug use before settling in Armopa. As per national health standards, they were given chloroquine for self prophylaxis during their first three months after arrival; thereafter, treatment with only chloroquine was provided for uncomplicated cases of clinical malaria. Chloroquine is widely used for treatment of clinical malaria among transmigrants and is dispensed through a health clinic in each settlement.

Blood samples were collected in 1996-1999 from study volunteers who were immigrants to the Armopa SP1 and SP2 sites and had no history of malaria or antimalarial drug use. Patients who were positive for malaria were treated at the health center with chloroquine, Fansidar ${ }^{\circledR}$, and quinine as the respective first-, second-, and third-line drugs for uncomplicated malaria as per the Indonesian National Health Policy. Chloroquine was given at a dose of $10 \mathrm{mg} / \mathrm{kg}$ on the first day,

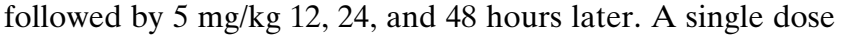
of Fansidar ${ }^{\circledR}(1 \mathrm{mg} / \mathrm{kg}$ of pyrimethamine and $20 \mathrm{mg} / \mathrm{kg}$ of sulfadoxine) was given if there was chloroquine treatment failure. This study was carried out after obtaining informed consent from all adult participants and from parents or legal guardians of minors, and was reviewed and approved by the Ethics Committees for Protection of Human Subjects at the Ministry of Health, Republic of Indonesia, the U.S. Navy Medical Research Unit No. 2 (Jakarta, Indonesia), and The 
TABLE 1

In vitro chloroquine responses and Plasmodium falciparum chloroquine resistance transporter (pfcrt) gene haplotypes among malaria patients in Armopa, Indonesian Papua*

\begin{tabular}{|c|c|c|c|c|c|c|c|}
\hline \multirow[b]{2}{*}{ Patient } & \multirow{2}{*}{$\begin{array}{c}\text { Sampling } \\
\text { date }\end{array}$} & \multirow{2}{*}{$\begin{array}{l}\text { In vivo } \\
\text { response }{ }^{\dagger}\end{array}$} & \multicolumn{5}{|c|}{ pfcrt codons } \\
\hline & & & 72 & 73 & 74 & 75 & 76 \\
\hline CQ004 & $12 / 6 / 96$ & RI & $\mathbf{S}$ & V & M & $\mathrm{N}$ & $\mathbf{T}$ \\
\hline CQ008 & $12 / 7 / 96$ & RI & $\mathbf{S}$ & V & M & $\mathrm{N}$ & $\mathbf{T}$ \\
\hline CQ010 & $3 / 10 / 97$ & RI & $\mathbf{S}$ & V & M & $\mathrm{N}$ & $\mathbf{T}$ \\
\hline CQ010 & $4 / 12 / 97$ & RIII & $\mathbf{S}$ & V & M & $\mathrm{N}$ & $\mathbf{T}$ \\
\hline CQ017 & $5 / 2 / 97$ & RIII & $\mathbf{S}$ & V & M & $\mathrm{N}$ & $\mathbf{T}$ \\
\hline CQ039 & $1 / 26 / 97$ & RI & $\mathbf{S}$ & V & M & $\mathrm{N}$ & $\mathbf{T}$ \\
\hline CQ039 & $4 / 24 / 97$ & RI & $\mathbf{S}$ & V & M & $\mathrm{N}$ & $\mathbf{T}$ \\
\hline CQ041 & 9/4/97 & RIII & $\mathbf{S}$ & V & M & $\mathrm{N}$ & $\mathbf{T}$ \\
\hline CQ042 & $5 / 8 / 97$ & RIII & $\mathbf{S}$ & V & M & $\mathrm{N}$ & $\mathbf{T}$ \\
\hline CQ044 & 4/13/97 & RIII & $\mathbf{S}$ & V & M & $\mathrm{N}$ & $\mathbf{T}$ \\
\hline CQ044 & 7/8/97 & RIII & $\mathbf{S}$ & V & M & $\mathrm{N}$ & $\mathbf{T}$ \\
\hline CQ054 & $5 / 3 / 97$ & RIII & $\mathbf{S}$ & V & $\mathrm{M}$ & $\mathrm{N}$ & $\mathbf{T}$ \\
\hline CQ055 & $5 / 4 / 97$ & RIII & $\mathbf{S}$ & V & M & $\mathrm{N}$ & $\mathbf{T}$ \\
\hline CQ060 & $5 / 8 / 97$ & RIII & $\mathbf{S}$ & V & M & $\mathrm{N}$ & $\mathbf{T}$ \\
\hline CQ062 & 5/14/97 & RIII & $\mathbf{S}$ & V & M & $\mathrm{N}$ & $\mathbf{T}$ \\
\hline CQ072 & $12 / 4 / 96$ & RI & $\mathbf{S}$ & V & M & $\mathrm{N}$ & $\mathbf{T}$ \\
\hline CQ091 & 4/16/97 & RI & $\mathbf{S}$ & V & M & $\mathrm{N}$ & $\mathrm{T}$ \\
\hline CQ101 & $1 / 15 / 97$ & RIII & $\mathbf{S}$ & V & M & $\mathrm{N}$ & $\mathbf{T}$ \\
\hline CQ118 & $11 / 9 / 97$ & RII & $\mathbf{S}$ & V & M & $\mathrm{N}$ & $\mathbf{T}$ \\
\hline CQ041 & 8/10/97 & RIII & $\mathbf{S}$ & V & M & $\mathrm{N}$ & $\mathbf{T}$ \\
\hline CQ041 & 10/30/97 & RIII & $\mathbf{S}$ & V & M & $\mathrm{N}$ & $\mathbf{T}$ \\
\hline CQ072 & $4 / 21 / 97$ & RIII & $\mathbf{S}$ & V & $\mathrm{M}$ & $\mathrm{N}$ & $\mathbf{T}$ \\
\hline CQ080 & $5 / 5 / 97$ & RIII & $\mathrm{S}$ & $\mathrm{V}$ & M & $\mathrm{N}$ & $\mathbf{T}$ \\
\hline CQ080末 & 7/29/97 & RI & $\mathbf{S}$ & V & M & $\mathrm{N}$ & $\mathbf{T}$ \\
\hline CQ076 & $10 / 15 / 96$ & RIII & $\mathbf{S}$ & V & I & $\mathbf{E}$ & $\mathbf{T}$ \\
\hline CQ104 & 5/2/97 & RIII & $\mathbf{S}$ & V & I & $\mathbf{E}$ & $\mathbf{T}$ \\
\hline CQ106 & $11 / 6 / 96$ & RIII & $\mathbf{S}$ & V & I & $\mathbf{E}$ & $\mathbf{T}$ \\
\hline CQ020 & $3 / 11 / 97$ & RIII & $\mathbf{S}$ & $\mathrm{V}$ & I & $\mathbf{E}$ & $\mathbf{T}$ \\
\hline CQ116 & $5 / 3 / 97$ & RIII & $\mathbf{S}$ & V & I & $\mathbf{E}$ & $\mathbf{T}$ \\
\hline CQ026 & 3/15/97 & RIII & $\mathbf{S}$ & V & I & $\mathbf{E}$ & $\mathbf{T}$ \\
\hline CQ078 & 8/29/97 & RIII & $\mathrm{C}$ & V & I & $\mathbf{E}$ & $\mathbf{T}$ \\
\hline CQ078 & $11 / 26 / 97$ & RIII & $\mathrm{C}$ & $\mathrm{V}$ & I & $\mathbf{E}$ & $\mathbf{T}$ \\
\hline CQ077 & 2/28/97 & RIII & $\mathrm{C}$ & V & I & $\mathbf{E}$ & $\mathbf{T}$ \\
\hline CQ082 & $11 / 8 / 97$ & RIII & $\mathrm{C}$ & V & I & $\mathbf{E}$ & $\mathbf{T}$ \\
\hline CQ094 & 3/23/97 & RIII & $\mathrm{C}$ & V & I & $\mathbf{E}$ & $\mathbf{T}$ \\
\hline CQ113 & $10 / 12 / 97$ & RII & $\mathrm{C}$ & V & I & $\mathbf{E}$ & $\mathbf{T}$ \\
\hline CQ118 & 2/15/97 & RIII & $\mathrm{C}$ & V & I & $\mathbf{E}$ & $\mathbf{T}$ \\
\hline CQ128 & $3 / 15 / 97$ & RIII & $\mathrm{C}$ & V & I & $\mathbf{E}$ & $\mathbf{T}$ \\
\hline CQ073 & 2/3/97 & RIII & $\mathrm{C}$ & V & I & $\mathbf{E}$ & $\mathbf{T}$ \\
\hline CQ024 & $2 / 6 / 97$ & RIII & $\mathrm{C}$ & V & I & $\mathbf{E}$ & $\mathbf{T}$ \\
\hline CQ131 & $2 / 7 / 97$ & RII & $\mathrm{C}$ & V & I & $\mathbf{E}$ & $\mathbf{T}$ \\
\hline CQ003 & $1 / 21 / 97$ & RI & $\mathrm{C}$ & V & M & $\mathrm{N}$ & $\mathbf{T}$ \\
\hline CQ059 & 3/30/97 & RI & $\mathrm{C}$ & V & M & $\mathrm{N}$ & $\mathbf{T}$ \\
\hline CQ067 & 4/30/97 & RIII & $\mathrm{C}$ & V & M & $\mathrm{N}$ & $\mathbf{T}$ \\
\hline CQ022 & $4 / 4 / 97$ & RIII & $\mathrm{C}$ & $\mathrm{V}$ & $\mathrm{M}$ & $\mathrm{N}$ & $\mathbf{T}$ \\
\hline CQ022 & 4/23/97 & RIII & $\mathrm{C}$ & V & M & $\mathrm{N}$ & $\mathbf{T}$ \\
\hline CQ087 & $8 / 1 / 97$ & RIII & $\mathrm{C}$ & V & $\mathrm{M}$ & $\mathrm{N}$ & $\mathbf{T}$ \\
\hline CQ095 & $12 / 13 / 96$ & RI & $\mathrm{C}$ & V & $\mathrm{M}$ & $\mathrm{N}$ & $\mathbf{T}$ \\
\hline CQ105 & 4/13/97 & RI & $\mathrm{C}$ & V & M & $\mathrm{N}$ & $\mathbf{T}$ \\
\hline CQ036 & $4 / 26 / 97$ & RII & $\mathrm{C}$ & V & M & $\mathrm{N}$ & $\mathbf{T}$ \\
\hline CQ024 & $5 / 6 / 97$ & $\mathrm{~S}$ & $\mathrm{C}$ & V & M & $\mathrm{N}$ & $\mathrm{K}$ \\
\hline CQ027 & 2/6/97 & $\mathrm{S}$ & $\mathrm{C}$ & V & M & $\mathrm{N}$ & $\mathrm{K}$ \\
\hline CQ036 & $1 / 30 / 97$ & $\mathrm{~S}$ & $\mathrm{C}$ & V & M & $\mathrm{N}$ & $\mathrm{K}$ \\
\hline CQ042 & 2/4/97 & $\mathrm{S}$ & $\mathrm{C}$ & V & M & $\mathrm{N}$ & $\mathrm{K}$ \\
\hline CQ043 & 9/25/97 & $\mathrm{S}$ & $\mathrm{C}$ & V & M & $\mathrm{N}$ & $\mathbf{T}$ \\
\hline CQ051 & $1 / 24 / 97$ & $\mathrm{~S}$ & $\mathrm{C}$ & V & M & $\mathrm{N}$ & $\mathrm{K}$ \\
\hline CQ056 & $4 / 5 / 97$ & $\mathrm{~S}$ & $\mathrm{C}$ & V & M & $\mathrm{N}$ & $\mathrm{K}$ \\
\hline CQ091 & 7/30/98 & $\mathrm{S}$ & $\mathrm{C}$ & V & M & $\mathrm{N}$ & $\mathrm{K}$ \\
\hline CQ001 & $1 / 26 / 98$ & S & $\mathrm{C}$ & V & M & $\mathrm{N}$ & $\mathrm{K}$ \\
\hline CQ090 & 1/10/99 & $\mathrm{S}$ & $\mathrm{C}$ & V & M & $\mathrm{N}$ & $\mathrm{K}$ \\
\hline CQ062 & $5 / 5 / 98$ & $\mathrm{~S}$ & $\mathrm{C}$ & $\mathrm{V}$ & $\mathrm{M}$ & $\mathrm{N}$ & $\mathrm{K}$ \\
\hline CQ077 & $11 / 28 / 98$ & $\mathrm{~S}$ & $\mathrm{C}$ & V & M & $\mathrm{N}$ & $\mathrm{K}$ \\
\hline CQ022 & 2/25/97 & $\mathrm{S}$ & $\mathrm{C}$ & V & M & $\mathrm{N}$ & $\mathrm{K}$ \\
\hline CQ095 & $1 / 28 / 98$ & $\mathrm{~S}$ & $\mathrm{C}$ & V & M & $\mathrm{N}$ & $\mathrm{K}$ \\
\hline CQ058 & $11 / 13 / 97$ & $\mathrm{~S}$ & $\mathrm{C}$ & V & M & $\mathrm{N}$ & $\mathrm{K}$ \\
\hline CQ020 & $11 / 12 / 97$ & $\mathrm{~S}$ & $\mathrm{C}$ & V & $\mathrm{M}$ & $\mathrm{N}$ & $\mathrm{K}$ \\
\hline CQ060 & $10 / 17 / 98$ & S & $\mathrm{C}$ & V & M & $\mathrm{N}$ & $\mathrm{K}$ \\
\hline
\end{tabular}

TABLE 1 (Continued)

In vitro chloroquine responses and Plasmodium falciparum chloroquine resistance transporter (pfcrt) gene haplotypes among malaria patients in Armopa, Indonesian Papua* (Continued)

\begin{tabular}{|c|c|c|c|c|c|c|c|}
\hline \multirow[b]{2}{*}{ Patient } & \multirow{2}{*}{$\begin{array}{c}\text { Sampling } \\
\text { date }\end{array}$} & \multirow{2}{*}{$\begin{array}{l}\text { In vivo } \\
\text { response } \dagger\end{array}$} & \multicolumn{5}{|c|}{ pfcrt codons } \\
\hline & & & 72 & 73 & 74 & 75 & 76 \\
\hline CQ098 & $1 / 28 / 98$ & $\mathrm{~S}$ & $\mathrm{C}$ & V & M & $\mathrm{N}$ & K \\
\hline CQ0110 & 3/15/97 & $\mathrm{S}$ & $\mathrm{C}$ & V & M & $\mathrm{N}$ & K \\
\hline CQ0102 & 2/3/97 & $\mathrm{S}$ & $\mathrm{C}$ & V & M & $\mathrm{N}$ & K \\
\hline CQ113 & 7/12/98 & $\mathrm{S}$ & $\mathrm{C}$ & V & M & $\mathrm{N}$ & K \\
\hline
\end{tabular}

* Codon mutations are indicated in bold.

$\dagger \mathrm{R}=$ resistant; $\mathrm{S}=$ sensitive.

$\ddagger$ Sample from a patient with a recrudescent parasitemia that was not included in the statistical analysis.

Walter and Eliza Hall Institute of Medical Research (Melbourne, Australia) and the Papua New Guinea Medical Research Advisory Committee.

\section{RESULTS}

Of 85 patients, $21(24.7 \%)$ cases cleared their parasitemias within 72 hours, had no recurrence during 28 days of followup, and were classified as sensitive to chloroquine. Fifty patients had persistent or recurrent parasitemias and were classified as resistant to chloroquine. Data from 15 patient samples were excluded from analysis due to incomplete clinical histories, intercurrent infections with $P$. vivax, or an inability to amplify gene products. Samples were analyzed for mutations in the pfcrt gene after amplification by a polymerase chain reaction (PCR) of DNA extracted from blood samples, followed by restriction fragment length polymorphism (RFLP) analysis and DNA sequencing. ${ }^{13,14}$ The DNA from a drug-sensitive strain (D10) was used as a positive control to monitor PCR conditions. As expected, the PCR product was amplified with wild-type alleles of the $p f c r t$ gene. No PCR products were amplified in negative controls.

The results of $p f c r t$ mutational analysis of samples from 50 cases of chloroquine treatment failure are shown in Table 1. All 50 chloroquine-resistant samples carried the mutant $p f c r t$ $76 \mathrm{~T}$ allele. No mutation was detected at codon 73 , but variations were found at codons 72,74 , and 75 in 50 samples: SVMNT (24), CVIET (11), CVMNT (9), and SVIET (6). Statistical analysis (chi-square test with Yates' correction) showed that the pfcrt mutation at codon 76 was strongly associated with chloroquine resistance $(P<0.0001) .{ }^{15}$ Among the 21 chloroquine-sensitive samples, only one carried a mutated pfcrt 76 allele.

Analysis of RFLP results from amplification of chloroquine-resistant $P$. falciparum laboratory strains K1, W2mef, VNS, 7G8, a new isolate, 2300, from Timika on the southern coast of Indonesian Papua, and two isolates, F2382 and F1568, from Flores, Indonesia showed mutations in the pfcrt gene (Table 2). Seven of these chloroquine-resistant laboratory strains showed three different $p$ fcrt haplotypes with mutations at codons 74, 75, and 76: CVMNT (7G8), CVIKT (2300), and CVIET (K1, W2 mef, VNS, F2382, and F1568). The wild-type haplotype CVMNK was found in the chloroquine-sensitive control strain D10.

The Wosera region of East Sepik province in Papua New Guinea is highly endemic for malaria. Mutation analysis of the genes involved in chloroquine resistance from Papua New 
TABLE 2

In vitro chloroquine responses and Plasmodium falciparum chloroquine resistance transporter ( $p f c r t$ ) gene haplotypes among laboratory strains and field samples*

\begin{tabular}{|c|c|c|c|c|c|c|c|}
\hline \multirow[b]{2}{*}{ Strains/samples } & \multirow[b]{2}{*}{ Origin } & \multirow[b]{2}{*}{$\mathrm{MIC}_{50} \dagger$} & \multicolumn{5}{|c|}{ pfcrt codons } \\
\hline & & & 72 & 73 & 74 & 75 & 76 \\
\hline \multicolumn{8}{|l|}{ Laboratory strains } \\
\hline D10 & Papua New Guinea & 1 & $\mathrm{C}$ & $\mathrm{V}$ & M & $\mathrm{N}$ & $\mathrm{K}$ \\
\hline 2300 & Papua & 75 & $\mathrm{C}$ & $\mathrm{V}$ & I & $\mathbf{K}$ & $\mathbf{T}$ \\
\hline K1 & Thailand & 130 & $\mathrm{C}$ & $\mathrm{V}$ & I & $\mathbf{E}$ & $\mathbf{T}$ \\
\hline W2 mef & Southeast Asia & 100 & $\mathrm{C}$ & $\mathrm{V}$ & I & $\mathbf{E}$ & $\mathbf{T}$ \\
\hline VNS & Vietnam & 80 & $\mathrm{C}$ & $\mathrm{V}$ & $\mathbf{I}$ & $\mathbf{E}$ & $\mathbf{T}$ \\
\hline $\mathrm{F} 2382$ & Flores, Indonesia & 30 & $\mathrm{C}$ & $\mathrm{V}$ & I & $\mathbf{E}$ & $\mathbf{T}$ \\
\hline F1568 & Flores, Indonesia & 128 & $\mathrm{C}$ & $\mathrm{V}$ & I & $\mathbf{E}$ & $\mathbf{T}$ \\
\hline $7 \mathrm{G} 8$ & South America & 300 & $\mathrm{C}$ & $\mathrm{V}$ & $\mathrm{M}$ & $\mathrm{N}$ & $\mathbf{t}$ \\
\hline \multicolumn{8}{|c|}{ Field samples (from all Papua New Guinea) } \\
\hline DR1 & & 64.0 & $\mathbf{S}$ & $\mathrm{V}$ & M & $\mathrm{N}$ & $\mathbf{T}$ \\
\hline DR3 & & 64.0 & $\mathbf{S}$ & V & M & $\mathrm{N}$ & $\mathbf{T}$ \\
\hline DR9 & & 32.0 & $\mathbf{S}$ & $\mathrm{V}$ & M & $\mathrm{N}$ & $\mathbf{T}$ \\
\hline DR21 & & 32.0 & $\mathbf{S}$ & $\mathrm{V}$ & M & $\mathrm{N}$ & $\mathbf{T}$ \\
\hline DR24 & & 32.0 & $\mathbf{S}$ & $\mathrm{V}$ & M & $\mathrm{N}$ & $\mathbf{T}$ \\
\hline DR5 & & 16.0 & $\mathbf{S}$ & V & M & $\mathrm{N}$ & $\mathbf{T}$ \\
\hline DR12 & & 16.0 & $\mathbf{S}$ & $\mathrm{V}$ & M & $\mathrm{N}$ & $\mathbf{T}$ \\
\hline DR15 & & 16.0 & $\mathbf{S}$ & $\mathrm{V}$ & M & $\mathrm{N}$ & $\mathbf{T}$ \\
\hline DR22 & & 16.0 & $\mathbf{S}$ & $\mathrm{V}$ & M & $\mathrm{N}$ & $\mathbf{T}$ \\
\hline DR2 & & 32.0 & $\mathbf{S}$ & $\mathrm{V}$ & M & $\mathrm{N}$ & $\mathbf{T}$ \\
\hline DR11 & & 64.0 & C & V & M & $\mathrm{N}$ & $\mathbf{T}$ \\
\hline DR4 & & 32.0 & $\mathrm{C}$ & V & M & $\mathrm{N}$ & $\mathbf{T}$ \\
\hline DR18 & & 64.0 & C & V & M & $\mathrm{N}$ & $\mathbf{T}$ \\
\hline DR20 & & 16.0 & $\mathrm{C}$ & V & M & $\mathrm{N}$ & $\mathbf{T}$ \\
\hline DR23 & & 16.0 & C & V & M & $\mathrm{N}$ & $\mathbf{T}$ \\
\hline DR14 & & 2.0 & $\mathrm{C}$ & V & M & $\mathrm{N}$ & $\mathrm{K}$ \\
\hline DR17 & & 2.0 & C & V & M & $\mathrm{N}$ & $\mathrm{K}$ \\
\hline DR19 & & 8.0 & $\mathrm{C}$ & $\mathrm{V}$ & M & $\mathrm{N}$ & $\mathrm{K}$ \\
\hline DR10 & & 2.0 & $\mathrm{C}$ & V & M & $\mathrm{N}$ & $\mathrm{K}$ \\
\hline DR13 & & 2.0 & C & V & M & $\mathrm{N}$ & K \\
\hline DR16 & & 2.0 & $\mathrm{C}$ & V & M & $\mathrm{N}$ & K \\
\hline
\end{tabular}

* Codon mutations are indicated in bold.

$\uparrow$ For the laboratory strains, $50 \%$ mean inhibitory concentration $\left(\mathrm{MIC}_{50}\right)$ values are in nanomoles and were determined by an in vitro microtiter assay. ${ }^{31}$ For the field isolates, values are in picomoles and were calculated at the Australian Army Malaria Institute.

Guinea has shown the presence of $P$. falciparum isolates carrying the pfcrt SVMNT haplotype, which is usually found in South American parasites, but not the CVIET haplotype of Southeast Asian isolates. ${ }^{16}$ The results of mutational analysis of 21 samples of $P$. falciparum obtained from malaria patients in Papua New Guinea are shown in Table 2. Fifteen of these samples with chloroquine minimum inhibitory concentrations (MICs) between 16 and $64 \mathrm{pmol}$ had the 76T allele. However, six isolates with MICs of 2-8 pmol had the wild-type $p f c r t$ allele at codons $72,73,74,75$, and 76 . There were three $p f c r t$ haplotypes among the 21 Papua New Guinea samples (Table 2). The wild-type haplotype CVMNK was observed in isolates with MIC values of 2-8 pmol, while the chloroquine-resistant pfcrt haplotypes CVMNT and SVMNT were observed in samples with MICs between 16 and 64 pmol.

\section{DISCUSSION}

Although chloroquine resistance in $P$. falciparum has been reported in Indonesia and Papua New Guinea since the early 1970 s, molecular analysis and in vitro/in vivo responses to antimalaria drugs have only recently been determined in this region. This study analyzed the association of mutations in

TABLE 3

Geographic distribution of Plasmodium falciparum chloroquine resistance transporter ( $p f c r t)$ gene haplotypes among chloroquine-resistant strains of P. falciparum*

\begin{tabular}{|c|c|c|c|c|c|c|}
\hline \multicolumn{5}{|c|}{ pfcrt codons } & \multirow{2}{*}{$\begin{array}{l}\text { Chloroquine } \\
\text { susceptibility }\end{array}$} & \multirow[b]{2}{*}{ Location } \\
\hline 72 & 73 & 74 & 75 & 76 & & \\
\hline $\mathrm{C}$ & $\mathrm{V}$ & M & $\mathrm{N}$ & $\mathrm{K}$ & Sensitive & \\
\hline $\mathrm{C}$ & $\mathrm{V}$ & M & $\mathrm{N}$ & $\mathbf{T}$ & Resistant & Papua, Papua New Guinea, South America \\
\hline $\mathrm{C}$ & $\mathrm{V}$ & I & $\mathbf{K}$ & $\mathbf{T}$ & Resistant & Papua \\
\hline $\mathrm{C}$ & $\mathrm{V}$ & $\mathbf{I}$ & $\mathbf{E}$ & $\mathbf{T}$ & Resistant & Papua, Southeast Asia, Africa \\
\hline $\mathbf{S}$ & V & I & $\mathbf{E}$ & $\mathbf{T}$ & Resistant & Papua \\
\hline $\mathbf{S}$ & $\mathrm{V}$ & M & $\mathrm{N}$ & $\mathbf{T}$ & Resistant & Papua, Papua New Guinea, South America \\
\hline
\end{tabular}

* Codon mutations are indicated in bold. 
the $p f c r t$ gene in samples of $P$. falciparum that had been characterized as chloroquine sensitive or resistant by in vitro or in vivo tests. ${ }^{14} \mathrm{~A}$ strong association between mutations in the pfcrt gene and chloroquine resistance $(P<0.0001)$ was observed in those samples from individuals who had chloroquine treatment failure in vivo or had displayed chloroquine MICs of 16-64 pmol in the in vitro test.

Studies to elucidate the molecular and biochemical mechanism of resistance to chloroquine have been in progress for more than a decade. Chloroquine resistance in $P$. falciparum involves decreased accumulation of the drug. However, the precise mechanism is not known. ${ }^{17}$ Mutations in the $P$. falciparum multidrug resistance 1 ( $p f m d r 1$ ) gene were implicated and involvement of at least two genes was hypothesized; mutations in both the $p f c r t$ and the $p f m d r 1$ genes appear to be necessary for resistance to chloroquine. ${ }^{13,18,19}$ A mutation in the $p$ fcrt gene (located on chromosome 7) at codon 76, with a change from lysine to threonine, has been invariably found in chloroquine-resistant strains and also in chloroquine-resistant field samples from Laos, Cameroon, Mozambique, Uganda, and South America. ${ }^{13,20-27}$ Transformation of chloroquinesensitive isolates with the Dd2 pfcrt gene sequence containing the 76T mutation consistently produced chloroquine-resistant clones, and insertion of the wild-type pfcrt gene caused resistant isolates to exhibit sensitivity to chloroquine. ${ }^{13}$ Studies on field isolates have shown the occurrence of three haplotypes of pfcrt gene alleles: CVMNK among chloroquine-sensitive isolates, CVIET among chloroquine-resistant isolates from Southeast Asia and Africa, and SVMNT among chloroquineresistant isolates from South America and Papua New Guinea. ${ }^{13,16,28}$ The presence of the 76T pfcrt gene mutation has been correlated with risk of therapeutic failure when malaria due to $P$. falciparum is treated with chloroquine..$^{22,29,30}$ Recently, an analysis of the genetic mutations associated with chloroquine resistance in an area highly endemic for malaria (the Wosera region of East Sepik province in Papua New Guinea) was also reported. ${ }^{16}$ All (100\%) samples from treatment failures (Indonesian Papua) and $67 \%$ of the isolates (Papua New Guinea) collected prior to treatment in the in vitro studies carry the mutated pfcrt allele 76 (Tables 1 and 2).

In this study, analyses of known laboratory isolates that are resistant to chloroquine showed the presence of a mutation in the $p f c r t$ gene. Samples collected in Papua New Guinea for in vitro chloroquine susceptibility testing provide further support for our data from clinical studies in Armopa. Although a mutated pfcrt codon 76 is invariably present in chloroquineresistant isolates, comparison of pfcrt haplotypes revealed some interesting features. In both Armopa (Papua) and Papua New Guinea, the CVMNK haplotype was the wild type. In Papua New Guinea, the chloroquine-resistant haplotypes detected were SVMNT and CVMNT, as demonstrated in other studies (Table 3). ${ }^{16,28}$ Interestingly, the $p f c r t$ haplotypes CVIET (African, Southeast Asian) and SVMNT (South American) were also detected in Papuan samples. In addition, two new pfcrt haplotypes were detected in Papua that have not been previously reported: SVIET, which was found in clinical samples isolated from cases of treatment failure in Armopa and CVIKT, a haplotype found in chloroquineresistant laboratory strain 2300, which was isolated in 1985 in Timika, Papua. The presence of African, South American, Southeast Asian, and two new chloroquine-resistant haplotypes in these regions raises the question of the evolution of these five haplotypes. They may have evolved by sequential mutations of the gene in this region, where the parasite is widely circulated, or the parasites with these haplotypes were transferred into this region. This speculation on the origin of haplotypes awaits detailed studies with data from other loci in the genomes of $P$. falciparum isolates.

In conclusion, our results support the hypothesis that the molecular basis of chloroquine resistance involves mutations in the pfcrt gene and that detection of a mutated pfcrt allele 76 could predict potential chloroquine treatment failures.

Received September 9, 2002. Accepted for publication December 4, 2002.

Acknowledgments: We thank Alan Cowman for supervision and encouragement during the course of this study; Sangkot Marzuki, Syafruddin, and Graham Brown for their encouragement and support; and Jenny Thompson and Deborah Baldi for providing the D10 parasite. We also thank the Ministry of Health, Republic of Indonesia for assistance in the collection of specimens in Armopa, Papua.

Financial support: This work was supported by the Australian and Indonesian Governments through the Australian Agency for International Development and Bappenas, respectively, and the Global Emerging Infections Surveillance program of the U.S. Department of Defense. Hadya S. Nagesha was supported by a Traveling Fellowship from the Wellcome Research Trust (United Kingdom).

Disclaimer: The views of the authors expressed herein are their own and do not purport or reflect those of the U.S. Navy or the U.S. Department of Defense.

Authors' addresses: Hadya S. Nagesha and Gerard J. Casey, The Walter and Eliza Hall Institute of Medical Research, 1G Royal Parade, Melbourne, 3050, Australia, Telephone: 62-3-934-52479, Fax: 62-3-934-70852, E-mail: hadya@wehi.edu.au and Eijkman Institute for Molecular Biology, Jl Diponegoro 69, Jakarta 10430, Indonesia. Karl H .Rieckmann, Australian Army Malaria Institute, Brisbane, Australia. David J. Fryauff, Budi S. Laksana, Jason D. Maguire, and J. Kevin Baird, United States Naval Medical Research Unit No.2, U.S. Embassy, Jakarta, Indonesia. John C. Reeder, Papua New Guinea Instititute of Medical Research, Goroka, Papua, New Guinea.

\section{REFERENCES}

1. WHO, 1987. World malaria situation 1985. World Health Stat $Q$ 40: $142-170$.

2. WHO, 1997. Malaria in the South-East Asia Region. New Delhi: Regional Office for South-East Asia, World Health Organization.

3. Meuwissen TJHE, 1964. The use of medicated salt in an antimalaria campaign in West New Guinea. Trop Geogr Med 16: 245-255.

4. Clyde DF, McCarthy VC, Miller RM, Hornick RB, 1976. Chloroquine-resistant falciparum malaria from Irian Jaya, Indonesian New Guinea. Am J Trop Med Hyg 79: 38-41.

5. Ebisawa I, Fukuyama T, 1975. Chloroquine resistance of Plasmodium falciparum in West Irian and East Kalimantan. Ann Trop Med Parasitol 69: 275-282.

6. Hoffman SL, Campbell J, Rustama D, Dimpudus AJ, Surumpaet B, 1987. Pyrimethamine-sulfadoxine still effective against Plasmodium falciparum in Jayapura, Irian Jaya: RI-type resistance in 2 of 18 patients. Trans $R$ Soc Trop Med Hyg 81: 276-277.

7. Hoffman SL, Harun S, Campbell JR, Purnomo, Marwoto HA, Dimpudus AJ, Rustama D, Oetoma HS, Rai NK, Laughlin LW, 1984. Prolonged incubation improves the micro-scale invitro test for drug sensitivity of Plasmodium falciparum. Lancet 1: 7-9.

8. Baird JK, Basri H, Purnomo, Bangs MJ, Subianto B, Patchen LC, Hoffman SL, 1991. Resistance to chloroquine by Plasmodium vivax in Irian Jaya, Indonesia. Am J Trop Med Hyg 44: $547-552$.

9. Baird JK, Wiady I, Fryauff DJ, Sutanihardja MA, Leksana B, Widjaya H, Kysdarmanto, Subianto B, 1997. In vivo resistance 
to chloroquine by Plasmodium vivax and Plasmodium falciparum at Nabire, Irian Jaya, Indonesia. Am J Trop Med Hyg 56: 627-631.

10. Fryauff DJ, Sumawinata I, Purnomo, Richie TL, Tjitra E, Bangs MJ, Kadir A, Ingkokusumo G, 1999. In vivo responses to antimalarials by Plasmodium falciparum and Plasmodium vivax from isolated Gag Island off northwest Irian Jaya, Indonesia. Am J Trop Med Hyg 60: 542-546.

11. Gomez-Saladin E, Fryauff DJ, Taylor WR, Laksana BS, Susanti AI, Purnomo, Subianto B, Richie TL, 1999. Plasmodium falciparum mdr1 mutations and in vivo chloroquine resistance in Indonesia. Am J Trop Med Hyg 61: 240-244.

12. Pribadi W, Sutanto I, Atmosoedjono S, Rasidi R, Surya LK, Susanto L, 1998. Malaria situation in several villages around Timika, south central Irian Jaya, Indonesia. Southeast Asian J Trop Med Public Health 29: 228-235.

13. Fidock DA, Nomura T, Talley AK, Cooper RA, Dzekunov SM, Ferdig MT, Ursos LM, Sidhu AB, Naude B, Deitsch KW, Su XZ, Wootton JC, Roepe PD, Wellems TE, 2000. Mutations in the $P$. falciparum digestive vacuole transmembrane protein PfCRT and evidence for their role in chloroquine resistance. Mol Cell 6: 861-871.

14. Nagesha HS, Din-Syafruddin, Casey GJ, Susanti AI, Fryauff DJ, Reeder JC, Cowman AF, 2001. Mutations in the pfmdrl, dhfr and dhps genes of Plasmodium falciparum are associated with in vivo drug resistance in Irian Jaya, Indonesia. Trans $R$ Soc Trop Med and Hyg 95: 43-49.

15. Dawson-Saunders B, Trapp RG, 1994. Basic and Clinical Biostatistics. Norwalk, CT: Appleton and Lange.

16. Mehlotra RK, Fujioka H, Roepe PD, Janneh O, Ursos LM, Jacobs-Lorena V, McNamara DT, Bockarie MJ, Kazura JW, Kyle DE, Fidock DA, Zimmerman PA, 2001. Evolution of a unique Plasmodium falciparum chloroquine-resistance phenotype in association with pfcrt polymorphism in Papua New Guinea and South America. Proc Natl Acad Sci USA 98: 12689-12694.

17. Krogstad DJ, Gluzman IY, Kyle DE, Oduola AM, Martin SK, 1987. Efflux of chloroquine from Plasmodium falciparum: mechanism of chloroquine resistance. Science 238: 1283-1285.

18. Foote SJ, Kyle DE, Martin RK, Oduola AMJ, Forsyth K, Kemp DJ, Cowman AF, 1990. Several alleles of the multidrugresistance gene are closely linked to chloroquine resistance in Plasmodium falciparum. Nature 345: 255-258.

19. Reed MB, Saliba KS, Caruana SR, Kirk K, Cowman AF, 2000. Pgh1 modulates sensitivity and resistance to multiple antimalarials in Plasmodium falciparum. Nature 403: 906-909.

20. Basco LK, Ringwald P, 2001. Analysis of the key pfcrt point mutation and in vitro and in vivo response to chloroquine in Yaounde, Cameroon. J Infect Dis 183: 1828-1831.

21. Cooper RA, Ferdig MT, Su XZ, Ursos LM, Mu J, Nomura T, Fujioka H, Fidock DA, Roepe PD, Wellems TE, 2002. Alter- native mutations at position 76 of the vacuolar transmembrane protein PfCRT are associated with chloroquine resistance and unique stereospecific quinine and quinidine responses in Plasmodium falciparum. Mol Pharmacol 61: 35-42.

22. Djimde A, Doumbo OK, Cortese JF, Kayentao K, Doumbo S, Diourte Y, Dicko A, Su XZ, Nomura T, Fidock DA, Wellems TE, Plowe CV, Coulibaly D, 2001. A molecular marker for chloroquine-resistant falciparum malaria. $N$ Engl J Med 344: 257-263.

23. Kyosiimire-Lugemwa J, Nalunkuma-Kazibwe AJ, Mujuzi G, Mulindwa H, Talisuna A, Egwang TG, 2002. The Lys-76-Thr mutation in PfCRT and chloroquine resistance in Plasmodium falciparum isolates from Uganda. Trans $R$ Soc Trop Med Hyg 96: 91-95.

24. Mayor AG, Gomez-Olive X, Aponte JJ, Casimiro S, Mabunda S, Dgedge M, Barreto A, Alonso PL, 2001. Prevalence of the K76T mutation in the putative Plasmodium falciparum chloroquine resistance transporter (pfcrt) gene and its relation to chloroquine resistance in Mozambique. J Infect Dis 183: 14131416.

25. Pillai DR, Labbe AC, Vanisaveth V, Hongvangthong B, Pomphida S, Inkathone S, Zhong K, Kain KC, 2001. Plasmodium falciparum malaria in Laos: chloroquine treatment outcome and predictive value of molecular markers. J Infect Dis 183: 789-795.

26. Su X-Z, Kirkman LA, Fujioka H, Wellems TE, 1997. Complex polymorphisms in an $\sim 330 \mathrm{kDa}$ protein are linked to chloroquine-resistant $P$ falciparum in Southeast Asia and Africa. Cell 91: 593-603.

27. Vieira PP, das Gracas Alecrim M, da Silva LH, GonzalezJimenez I, Zalis MG. 2001. Analysis of the PfCRT K76T mutation in Plasmodium falciparum isolates from the Amazon region of Brazil. J Infect Dis 183: 1832-1833.

28. Wootton JC, Feng X, Ferdig MT, Cooper RA, Mu J, Baruch DI, Magill AJ, Su X-Z, 2002. Genetic diversity and chloroquine selective sweeps in Plasmodium falciparum. Nature 418: 320 323.

29. Babiker HA, Pringle SJ, Abdel-Muhsin A, Mackinnon M, Hunt $\mathrm{P}$, Walliker D, 2001. High-level chloroquine resistance in Sudanese isolates of Plasmodium falciparum is associated with mutations in the chloroquine resistance transporter gene $p$ fcrt and the multidrug resistance gene pfmdr1. J Infect Dis 183: $1535-1538$.

30. Maguire JD, Susanti AI, Krisin, Sismadi P, Fryauff DJ, Baird JK, 2001. The T76 mutation in the pfcrt gene of Plasmodium falciparum and clinical chloroquine resistance phenotypes in Papua, Indonesia. Ann Trop Med Parasitol 95: 559-572.

31. Rieckmann KH, Campbell GH, Sax LJ, Mrema JE, 1978. Drug sensitivity of Plasmodium falciparum: an in vitro microtechnique. Lancet 1: 22-23. 